\title{
Decontamination of Pig Carcasses Using Water Pressure and Lactic Acid
}

\author{
Jean Carlos Brustolin ${ }^{1}$, Andreia Dal Pisol ${ }^{1}$, Juliana Steffens ${ }^{1 *}$, Geciane Toniazzo ${ }^{1}$, Eunice \\ Valduga $^{1}$, Marco Di Luccio ${ }^{2}$ and Rogério Luis Cansian ${ }^{1}$ \\ ${ }^{1}$ Departamento de Engenharia de Alimentos; Universidade Regional Integrada do Alto Uruguai e das Missões; \\ Erechim - RS - Brasil. ${ }^{2}$ Departamento de Engenharia Química e Engenharia de Alimentos; Universidade Federal de \\ Santa Catarina;Florianópolis- SC - Brasil
}

\begin{abstract}
The objective of this work was to evaluate the effect of different water pressures and concentrations of lactic acid on microbial counts (mesophilic bacteria, enterobacteria and Salmonella) on pig carcasses without contamination and contaminated carcasses, before and after the last shower and before being cooled. The tests were carried out using 4, 3 and 2 bar water pressure, and 2, 1 and 0\% lactic acid concentration. In general, both the pressure in the shower and lactic acid had a positive effect by reducing the microbial count. The interaction between the pressure and lactic acid caused the largest reduction in carcasses surface count for mesophiles. With regard to enterobacteria on contaminated carcasses, the most important variable was the lactic acid concentration and in uncontaminated carcasses, it was water pressure. The use of 8 bar pressure of the wash water without lactic acid caused a reduction in mesophilic bacteria and enterobacteria, for both the contaminated and uncontaminated carcasses, with results statistically equal to each other, and significantly lower than the initial counts. The water pressure at 8 bar reduced the percentage of carcasses with Salmonella in contaminated carcasses.
\end{abstract}

Key words: Pig carcasses, decontamination, water pressure, lactic acid, bacteria

\section{INTRODUCTION}

The physico-chemical and microbiological conditions of meat products depend on measures that must be followed from the point of preslaughter to the time of consumption. The inside muscle of a healthy animal should be free of microbial contamination. Contamination of meat occurs inevitably during the slaughter and industrial processing and this is the main cause of deterioration (Ercoline et al. 2006). In the meat industry, dust, water and the faeces of animals that remain adhered to the skin are considered as the primary and direct sources of contamination of carcasses, especially Enterobacteriaceae (Mcevoy et al. 2000).
Several techniques have been recommended to control the process of deterioration of meat, involving the use of physical and chemical methods, among others. Noteworthy are the use of refrigeration or modified atmosphere, decontamination of carcasses by the use of organic acids or heated water, and the use of irradiation (Gill 2009). The safety and quality of foods such as fresh beef can be estimated by counting the number of indicator microorganisms (Lopes et al. 2007).

Many spoilage microorganisms are also pathogenic for humans or indicate the presence of these, as in the case of microorganisms from the family Enterobacteriaceae, which can cause public health problems (Bergey and Holt 1994). The

\footnotetext{
*Author for correspondence: julisteffens @uricer.edu.br
} 
presence of enteric bacteria is often used as an indicator of possible faecal contamination due to inappropriate processing or post-processing contamination (Tornadijo et al. 2001) associated with the handling of the meat and work surfaces.

In Brazil, the program of Hazard Analysis and Critical Control Points (HACCP) was established by the Circular No. 369 (Brasil 2003b) on June 2, 2003, set up by the DCI/DIPOA (Control Division of International Trade/Department of Inspection Animal Products, Brazil). The minimum critical control points (CCPs) to slaughter are contamination of carcass by faeces, intestinal content and milk, and no tolerance limit to the presence of these. The same program strongly recommends corrective actions to remove the faecal contamination by cutting of contaminated part and visual inspection. Under normal conditions of slaughter, despite swine carcasses presenting appropriate visual characteristics, they may be highly contaminated because their skin is a major source of contamination (Brasil 2003b).

Currently, European Union (EU) legislation (Regulation EC 2004) laying down specific hygiene rules for foodstuffs of animal origin in Article 3-2, mentions that food companies cannot use any chemical substance other than potable water to remove surface contamination from the products of animal origin. The regulation does not prohibit altogether the chemical decontamination of food of animal origin, but the approval is subject to stringent requirements and can only be authorized after the European Food Safety Authority (EFSA) has performed a risk analysis. However, the standard procedure in other countries involves washing in the housing before the cooling. In Canada, this toilet procedure is performed after the shower washing and before the cooling. Chemical treatments of carcasses are allowed in the United States of America.

Thus, studies on maintaining high standards of sanitation during slaughter are of extreme importance for improving the procedures for slaughterhouses in Brazil. Therefore, this study aimed to evaluate the reduction of surface contamination on swine carcasses using water pressure and lactic acid solution.

\section{MATERIALS AND METHODS}

\section{Sample Preparation}

The experiments were conducted in a pig meat industry located in southern Brazil and with permanent Federal Inspection Service. The effect of different water pressures and concentrations of lactic acid (Table 1) on microbial counts were evaluated (mesophilic bacteria, enterobacteria and Salmonella) on the carcass before and after the last shower (Fig. 1), before being cooled.
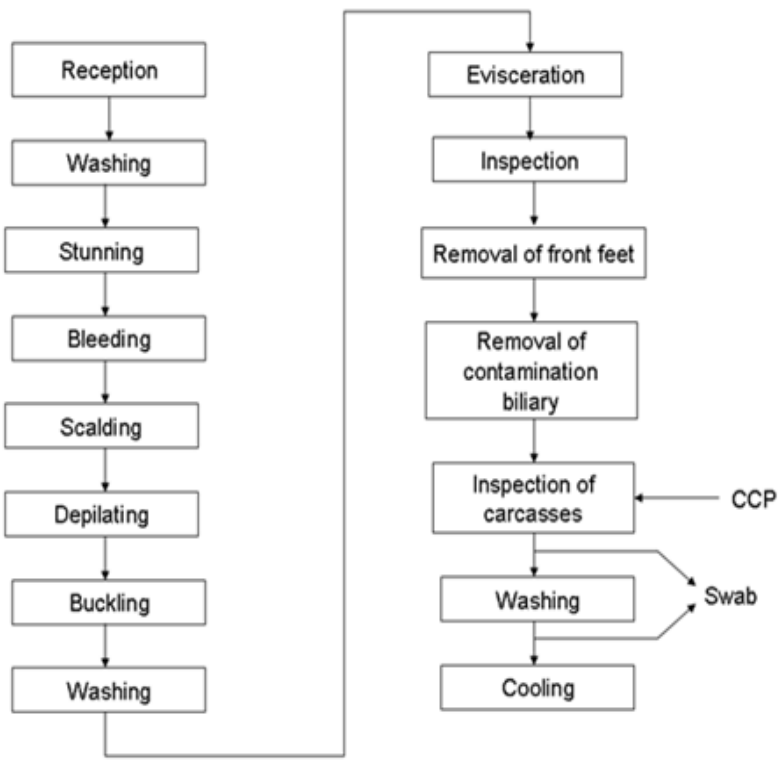

Figure 1 - Process of pig slaughter flowchart.

\section{Water spray pressure and lactic acid effects in the fecal decontamination of pork carcass}

The influence of water pressure and lactic acid concentration on faecal decontamination was evaluated by a central composite design $-2^{2}$ factorial design with three replications at the central point (Haalan 1989; Jung et al. 2003; Dal Pissol et al. 2013). The tests were conducted on carcasses that were shower washed (sprayed), located at the end of the evisceration line (Fig. 1), after the CCP, before entering the pre-cooling system. The independent variables and their levels are given in Table 1.

Table 1 - Independent variables and levels tested in factorial design $2^{2}$.

\begin{tabular}{lccc}
\hline \multirow{2}{*}{ Independent variables* } & \multicolumn{3}{c}{ Levels } \\
\cline { 2 - 4 } & +1 & 0 & -1 \\
\hline \multicolumn{1}{c}{ Water pressure (bar) } & 4 & 3 & 2 \\
Lactic acid concentration $(\%)$ & 2 & 1 & 0 \\
\hline *Fixed variables: Water temperature: & $22-23^{\circ} \mathrm{C}$, time of \\
carcasses passage by equipment (shower wash): 15 & seconds, \\
spray nozzles number: 32 (16 on each side).
\end{tabular}


The combinations of pressure and concentration of lactic acid of experiments 1 to 7 are detailed in Tables 2 and 3 . The variables water temperature $\left(22-23^{\circ} \mathrm{C}\right)$, contact time $(15 \mathrm{~s})$ and number of spray nozzles used in washing $(32,16$ on each side) were fixed. The dependent variables (responses) analyzed were: mesophilic and enterobacterial counts, and the presence or absence of Salmonella sp. on carcasses with and without contamination. The microbiological counts were performed after the shower. A manometer-scale bar was installed on the access duct of the shower to regulate the water pressure and the lactic acid spray was performed with a $500 \mathrm{~mL}$ applicator. The swabs were performed after $10 \mathrm{~min}$ of lactic acid application. Normal carcasses with no visible sign of faecal contamination were analyzed, as well as those that were purposely contaminated with faeces, according to the procedure described above. In each experiment, sponge swabs were collected from five normal carcasses and five contaminated carcasses, giving a total of 70 carcasses examined at this initial stage of the study.

Since lactic acid is not allowed to be used on pig carcasses according to Brazilian legislation, the effects of increasing the water pressure in the shower (8 bars, treatment 8 ) was studied, which corresponded to two times the pressure used in the initial part of the study. For this stage of the experiment, 24 pig carcasses that were obtained on the day of slaughter were used, with swabs performed on 12 normal carcasses showing no visible signs of any type of contamination and on the other 12 carcasses with a high level of faecal contamination.

\section{Experimental Validation}

After evaluating the results of the experiments, analyses were repeated to validate the experiment that gave the lowest microbial count. Microbiological tests were important to validate the best experiment and confirm that this was really effective in controlling microbiological counts on carcasses. The best experimental conditions were evaluated on 30 carcasses, which included 15 with no visible contamination and 15 with visible contamination (treatment 9).

\section{Microbiological analysis}

For microbiological analyses, 3M sponge swabs were used, hydrated previously with $10 \mathrm{~mL}$ of $0.1 \%$ peptone water. The results were expressed as colony forming units per $\mathrm{mL}(\mathrm{CFU} / \mathrm{mL})$ or its logarithm $(\log 10 \mathrm{CFU} / \mathrm{mL})$.

\section{Mesophiles count \\ Mesophilic bacterial counts were performed on $3 \mathrm{M}$ Petrifilm plates for aerobic bacteria $(3 \mathrm{M}$, Sumaré, Brazil). The analysis followed the Brazilian legislation (Brasil 2010).}

\section{Enterobacteria Count}

Enterobacterial counts were performed on $3 \mathrm{M}$ Petrifilm plates (3M, Sumaré, Brazil), using the validated method (Brasil 2003b).

\section{Salmonella Presence}

The BAX system was employed, which identified the Salmonella by detecting the DNA fragments present in the sample by Real-time PCR. The method used was in accordance with Instruction No. 40, dated 12/12/05 - Alternative Official Analytical Methods for Salmonella, Listeria monocytogenes and E. coli Isolation and Identification in Animal Products - Ministry of Agriculture and Food Supply - MAPA, Brazil. Salmonella analysis was performed only for the experiments with increased water pressure ( 8 bars) due to absence in experiments 1 to 7 .

\section{Statistical Analysis}

The results of the microbiological determinations (validation experiments) were subjected to variance analysis, followed by Tukey's test to compare the means of the results at the significance level of 5\% ( $\mathrm{p}<0.05)$. For statistical analysis, the STATISTICA software 7.0 was applied (StatSoft Inc ${ }^{\circledR}$, USA).

\section{RESULTS AND DISCUSSION}

\section{Evaluation of mesophilic bacteria count in the carcasses}

Table 2 presents the matrix of the $2^{2}$ factorial designs (real and coded values) and the mesophilic bacterial counts from normal (SC) and contaminated (CC) carcasses.

There was a significant reduction in microbial counts in all the experiments compared to the initial count (before CCP) for carcasses that were contaminated. In experiment 2 (2 bars and 2\% lactic acid), samples without contamination showed no changes in their microbial counts. Although different carcasses without contamination presented similar counts, certain 
batches might have had a high level of contamination, explaining the high counts found in some treatments of uncontaminated carcasses.

In carcasses contaminated with faecal material, the reduction in microbial counts ranged from $3.03 \mathrm{log}$ in experiment 7 (pressure 3 bars and $1 \%$ lactic acid) to $1.37 \log$ in experiment 1 (pressure 2 bars and without lactic acid). In uncontaminated carcasses, except in experiment 2, the reduction ranged from $0.26 \mathrm{log}$ in experiment 1 (pressure 2 bars without lactic acid) to $1.1 \log$ in experiment 5 (pressure 3 bars and 1\% lactic acid).

Table - 2 Matrix of $2^{2}$ factorial designs (real and coded values) and the responses of mesophilic bacteria counts in normal line carcasses (SC) and those who were contaminated (CC).

\begin{tabular}{|c|c|c|c|c|}
\hline \multirow[b]{2}{*}{ Experiment } & \multicolumn{2}{|c|}{ Independent variables } & \multicolumn{2}{|c|}{ * mesophilic bacteria counts (Log CFU/cm²) } \\
\hline & $\begin{array}{c}\text { Water pressure } \\
\text { (bar) }\end{array}$ & $\begin{array}{c}\text { Acid lactic } \\
\text { concentration (\%) }\end{array}$ & $\begin{array}{c}\text { Uncontaminated } \\
\text { carcasses }\end{array}$ & $\begin{array}{c}\text { Contaminated } \\
\text { carcasses }\end{array}$ \\
\hline (a) & 0.0 & 0.0 & $4.91^{\mathrm{a}}$ & $7.47^{\mathrm{a}}$ \\
\hline 1 & $-1(2.0)$ & $-1(0.0)$ & $4.65^{b}$ & $6.10^{\mathrm{b}}$ \\
\hline 2 & $-1(2.0)$ & $+1(2.0)$ & $5.61^{\mathrm{a}}$ & $5.62^{\mathrm{b}}$ \\
\hline 3 & $+1(4.0)$ & $-1(0.0)$ & $5.58^{\mathrm{b}}$ & $5.90^{\mathrm{b}}$ \\
\hline 4 & $+1(4.0)$ & $+1(2.0)$ & $4.36^{\mathrm{b}}$ & $5.95^{\mathrm{b}}$ \\
\hline 5 & $0(3.0)$ & $0(1.0)$ & $3.81^{\mathrm{c}}$ & $5.92^{\mathrm{b}}$ \\
\hline 6 & $0(3.0)$ & $0(1.0)$ & $4.22^{\mathrm{bc}}$ & $4.49^{\mathrm{b}}$ \\
\hline 7 & $0(3.0)$ & $0(1.0)$ & $3.82^{\mathrm{c}}$ & $4.45^{\mathrm{b}}$ \\
\hline
\end{tabular}

(a) Initial contamination * average of counts in the columns followed by the same letter, indicate no significant difference at the $5 \%$ level (Tukey test).

Pipek et al. (2006) evaluated under industrial conditions the reduction of psychrotrophic and mesophilic microorganisms on the surfaces of pig carcasses subjected to steam treatment and spraying with $2 \%$ lactic acid. The treatment was performed $30 \mathrm{~min}$ after the slaughter and the carcasses were evaluated immediately after the treatment and during storage of up to five days. They concluded that the treatment was effective in reducing the surface count immediately and slowed bacterial growth during the storage.

Figure 2 shows the Pareto charts with the estimated effects of the variables water pressure (bar) and lactic acid concentration on mesophilic bacterial counts on carcasses with (A) and without (B) contamination. It was observed that increased water pressure together with the use of lactic acid caused the maximum reductions in mesophilic bacterial counts on carcasses without contamination.

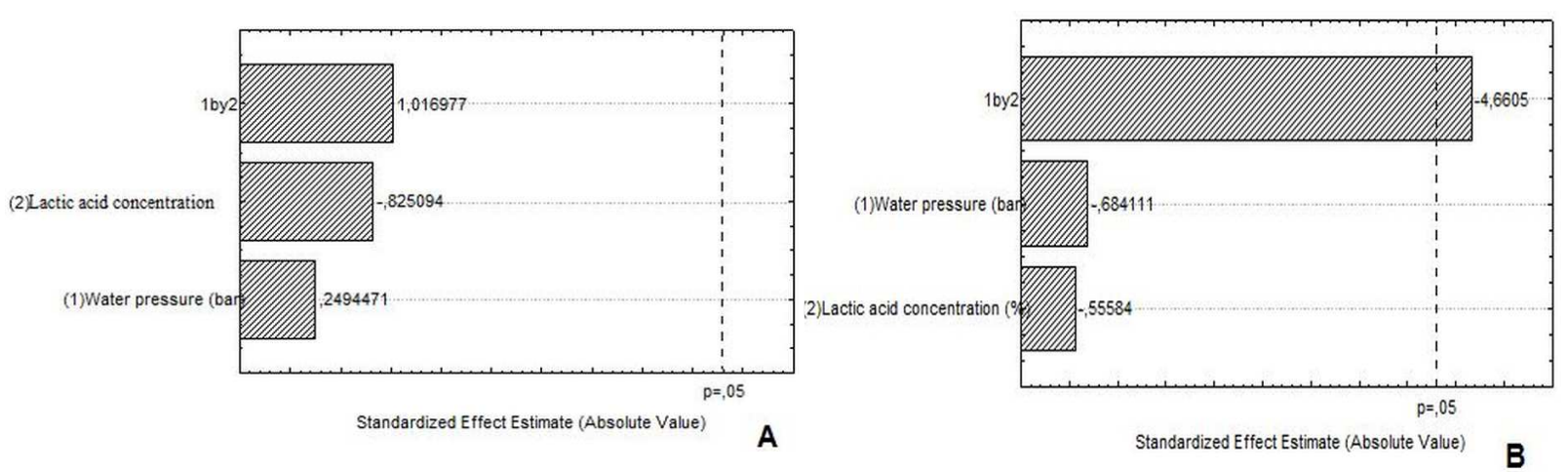

Figure 2 - Pareto chart with estimated effect of the variables in the experimental $2^{2}$ for mesophilic bacteria on previously contaminated carcasses $\mathrm{d}(\mathrm{A})$ and uncontaminated (B), respectively.

\section{Evaluation of enterobacteria count in the carcasses}

Table 3 presents the matrix of the $2^{2}$ factorial designs (real and coded values) and the enterobacterial counts on normal (SC) and contaminated (CC) carcasses. There was a significant reduction $(p<0.05)$ in the counts in almost all the experiments with respect to the 
initial count (before CCP), except in experiment 2 (2 bars and 2\% lactic acid) with uncontaminated carcasses, where the count actually increased $(0.48$ $\log \mathrm{CFU} / \mathrm{cm}^{2}$ ). This was also seen with the mesophilic bacterial counts (Table 2) and in experiment 1 ( 2 bars and no lactic acid) with contaminated carcasses, where the reduction from the initial count was not significant.

The enterobacterial reduction ranged from 0.83 (Experiment 1) to $4.01 \log \mathrm{CFU} / \mathrm{cm}^{2}$ (Experiment 5) on contaminated carcasses. In uncontaminated carcasses, except for those in experiment 2, there were reductions varying from 1.87 (Experiment 1) to 2:42 $\log \mathrm{CFU} / \mathrm{cm}^{2}$ (Experiment 5). In general, the different treatments were effective in reducing enterobacterial counts in relation to the mesophilic bacteria.

These results were similar to those found by Smulders et al. (2012), who investigated the numbers of enterobacteria, Pseudomonas fragi and Yersinia enterocolitica (6 to $7 \log \mathrm{CFU} / \mathrm{cm}^{2}$ ) in the samples of skin and stomach from pig carcasses subjected to different water pressures and treatment for $15 \mathrm{~s}$ with spray water at $55^{\circ} \mathrm{C}$. This treatment reduced bacterial counts of the order 2-4 log contamination.

The enterobacterial reduction mainly on normal carcasses without contamination was similar to those found by Pearce et al. (2004), who determined the critical control points in the slaughter of pigs, and Spescha et al. (2006), who evaluated microbiological contamination of pig carcasses, studying the effects of time (5 to 8.5 $\mathrm{min})$ and scalding temperatures $\left(59-62^{\circ} \mathrm{C}\right)$ that reduced enterobacterial counts by 1.7 to $3.3 \mathrm{log}$ $\mathrm{CFU} / \mathrm{cm}^{2}$.

Van Netten et al. (1997) evaluated the surfaces of pig carcasses inoculated in a laboratory, in which a spray of lactic acid was applied, ranging from 1 to
$2 \%$, at $55^{\circ} \mathrm{C}$ for $0.5 \mathrm{~min}$. They observed a significant reduction of aerobic bacteria and enterobacteria from 0.4 to $1.7 \log \mathrm{CFU} / \mathrm{cm}^{2}$, lower than those found on contaminated carcasses in the present study (Table 3), which were between 0.83 (Experiment 1) and $2.15 \quad \log \mathrm{CFU} / \mathrm{cm}^{2}$ (Experiment 7). When the lactic acid concentration was increased to $5 \%$ at $55^{\circ} \mathrm{C}$ and the time from 0.5 to $1.5 \mathrm{~min}$, they observed reductions in the aerobic bacterial and enterobacterial counts from 1 to 1.7 and $2.7 \log \mathrm{CFU} / \mathrm{cm}^{2}$, respectively. These results were similar to those found on the uncontaminated carcasses in this study (Table 3), with reductions ranging from 1.87 (Experiment 1) to $2.42 \mathrm{log}$ CFU/ $\mathrm{cm}^{2}$ (Experiment 5).

Figure 3 shows the Pareto Charts with the estimated effects of the variables water pressure (bar) and lactic acid concentration on enterobacterial counts on contaminated (A) and uncontaminated (B) carcasses. In the contaminated carcasses (A), the increase in water pressure or the use of lactic acid significantly decreased enterobacterial counts.

Moreover, lactic acid had a greater effect on reducing counts than increased water pressure on contaminated carcasses.

On uncontaminated carcasses (B), only the water pressure had a negative significant effect, reducing the enterobacterial counts, while the lactic acid showed a positive significant effect $(\mathrm{p}<0.05)$. Since the initial results showed that lactic acid efficiently removed the bacteria from pig carcasses, along with increased water pressure, and given that Brazilian law would not allow the use of lactic acid, the focus of the study was put on physical treatment only in the later stage of this study, where water pressure in the shower was increased to 8 bars.

Table 3 - Matrix of $2^{2}$ factorial designs (real and coded values) and the responses of enterobacteria counts in uncontaminated carcasses (SC) and contaminated (CC).

Independent variables $*$ enterobacteria counts $\left(\log \mathrm{CFU} / \mathrm{cm}^{2}\right)$ Experiment Water pressure (bar) Acid lactic concentration (\%) $\quad$ Uncontaminated carcasses Contaminated carcasses

\begin{tabular}{ccccc}
\hline a) & 0.0 & 0.0 & $3.35^{\mathrm{a}}$ & $7.07^{\mathrm{a}}$ \\
1 & $-1(2.0)$ & $-1(0.0)$ & $1.48^{\mathrm{b}}$ & $6.24^{\mathrm{a}}$ \\
2 & $-1(2.0)$ & $+1(2.0)$ & $3.83^{\mathrm{a}}$ & $4.42^{\mathrm{b}}$ \\
3 & $+1(4.0)$ & $-1(0.0)$ & $1.00^{\mathrm{c}}$ & $5.00^{\mathrm{b}}$ \\
4 & $+1(4.0)$ & $0(1.0)$ & $1.46^{\mathrm{b}}$ & $4.34^{\mathrm{b}}$ \\
5 & $0(3.0)$ & $0(1.0)$ & $0.93^{\mathrm{c}}$ & $3.06^{\mathrm{c}}$ \\
6 & $0(3.0)$ & $0(1.0)$ & $1.40^{\mathrm{b}}$ & $3.60^{\mathrm{c}}$ \\
7 & $0(3.0)$ & $1.20^{\mathrm{b}}$ & $3.39^{\mathrm{c}}$ \\
\hline
\end{tabular}

(a)Initial contamination * average of counts in the columns followed by the same letter, indicate no significant difference at the $5 \%$ level (Tukey test). 


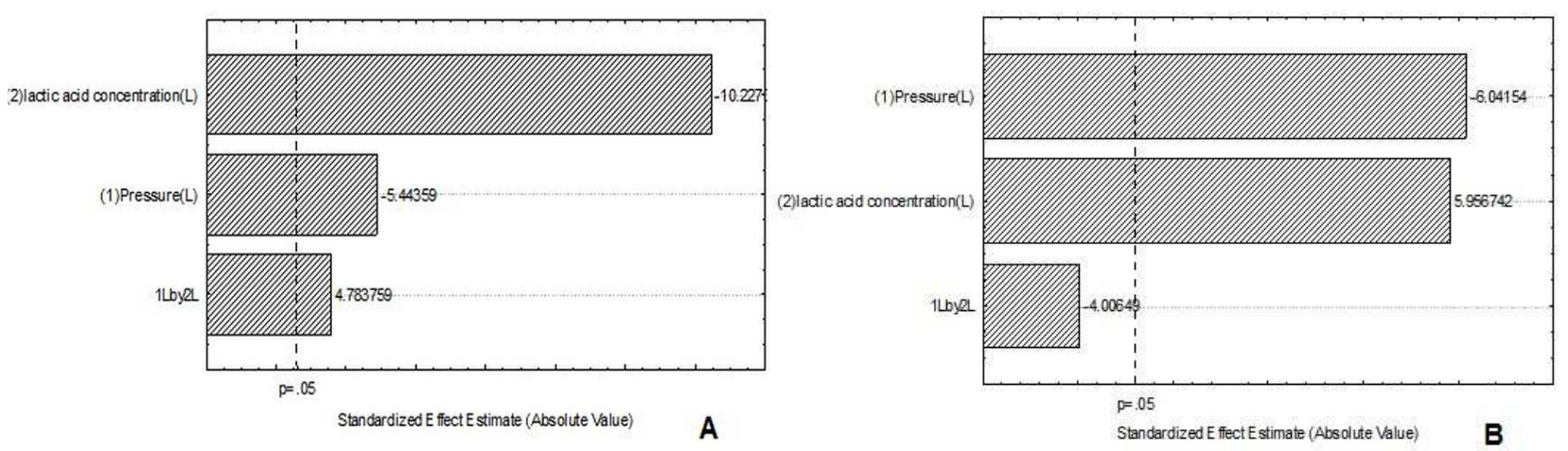

Figure 3 - Pareto chart with estimated effect of the variables in the experimental $2^{2}$ for enterobacteria on previously contaminated carcasses (A) and uncontaminated (B), respectively.

\section{Validation of results}

Figure 4 shows the initial mesophilic bacterial counts in treatment 5 (best experimental condition), treatment 8 (using 8 bars of water pressure) and treatment 9 (validation of results) for the uncontaminated (SC) and contaminated (CC) carcasses.

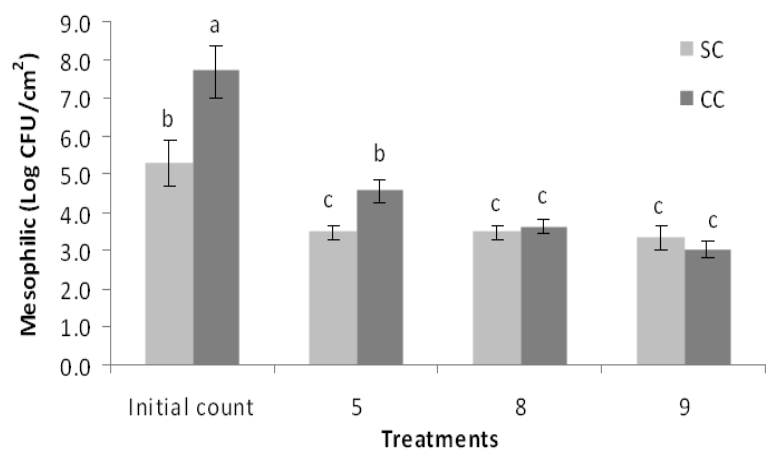

Figure 4 - Initial mesophilic bacteria counts, treatment 5 (best experimental condition), treatment 8 ( 8 bar water pressure) and treatment 9 (validation of results with 8 bar), uncontaminated carcasses (SC) and those who were contaminated (CC).

At 8 bars, the mesophilic bacterial count was significantly reduced $(\mathrm{p}<0.05)$, compared with the initial count (CC and SC) and treatment 5 (CC). In other words, the application of increased pressure was effective in reducing the mesophilic bacterial count. Moreover, treatments 8 and 9 did not produce significantly different results. These results indicated that washing carcasses with a water pressure of 8 bars could replace the method of cutting out contaminated parts recommended by Circular No. 369 (Brasil 2003a).
Regarding enterobacteria (Fig. 5), there was also a reduction in the count (treatments 8 and 9), compared to the initial count (CC and $\mathrm{SC}$ ) and treatment $5(\mathrm{CC})$.

Treatment with 8 bars reduced enterobacterial counts to acceptable levels $\left(1.03 \mathrm{CFU} / \mathrm{m}^{2}\right.$ for SC and $2.30 \mathrm{CFU} / \mathrm{m}^{2}$ for $\mathrm{CC}$ ). However, there was a difference of approximately one log cycle between the uncontaminated and contaminated carcasses after the treatments. In the contaminated carcasses (CC), $8 \%$ exhibited no signs of Salmonella. After the application of the 8-bar water pressure, $80 \%$ of the carcasses showed the absence of Salmonella. These results indicated that the water pressure significantly decreased Salmonella contamination of the carcasses. In uncontaminated carcasses, $100 \%$ showed the absence of Salmonella before the treatment with a water pressure of 8 bars, making it impossible to evaluate the reduction.

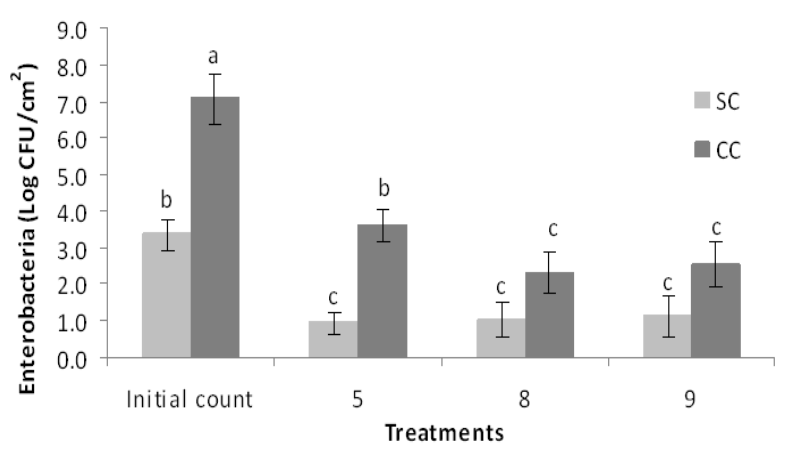

Figure 5 - Initial enterobacteria counts, treatment 5 (best experimental condition), treatment 8 ( 8 bar water pressure) and treatment 9 (validation of results with 8 bar), uncontaminated carcasses (SC) and those who were contaminated (CC). 
Bessa et al. (2004) studied the presence of Salmonella sp in the pigs slaughtered at RS, observing that of the 300 pigs sampled, 56\% showed the signs of Salmonella sp. The high Salmonella incidence found by different studies indicated the need to apply a treatment on the carcasses to reduce this incidence. The reduction indices obtained in this study showed that washing the carcasses at a water pressure of 8 bars could decrease the incidence of Salmonella.

The results presented above were in agreement with the recommendation of the International Commission on Microbiological Specifications (ICMSF) (Gill 2009), which indicated that in the case of a cut and rupture of the gut during evisceration, the carcasses should be washed to eliminate the visible contamination. This practice could reduce enteric bacteria (e.g., coliforms, $E$. coli and Salmonella) in carcasses without apparent contamination.

In general, both the water pressure in the shower and the lactic acid treatment had a positive effect by reducing microbial counts on the surfaces of pig carcasses. The use of 8 bars without lactic acid lowered the mesophilic bacterial and enterobacterial counts on both the contaminated and uncontaminated carcasses and decreased the incidence of Salmonella on contaminated carcasses. These results demonstrated that washing carcasses with a water pressure of 8 bars could replace the method of cutting out the contaminated parts from carcasses, without affecting the microbial quality and reducing the risk of crosscontamination through handling. The technique of removing visible faecal contamination from pig carcasses with drinking water at adequate pressures could be widely applied around the world, contributing to the maintenance of acceptable microbiological quality and minimizing the costs for this food sector.

\section{CONCLUSIONS}

Based on the results obtained in this work, both the pressure in the shower and lactic acid had a positive effect by reducing the microbial count on the surface of pig carcasses. The interaction between the pressure and lactic acid resulted the maximum reduction in carcasses surface count for the mesophilic bacteria. With regard to enterobacteria on the contaminated carcasses, the most important variable was the lactic acid concentration, which for the uncontaminated carcasses, was the water pressure. The use of 8 bar pressure of the wash water without lactic acid resulted reduction in mesophilic bacterial count and enterobacteria for both the contaminated and uncontaminated carcasses, with results statistically equal to each other, and significantly lower than the initial counts. The water pressure at 8 bar favored reducing the percentage of presence of Salmonella in contaminated carcasses.

\section{ACKNOWLEDGMENTS}

The authors thank the CNPq, FAPERGS and SCIT RS for financial support.

\section{REFERENCES}

Bergey DH, Holt JG. Bergey's manual of determinative bacteriology. 9th ed. Baltimore: Williams \& Wilkins. 1994.

Bessa MC, Costa M, Cardoso M. Prevalence of Salmonella sp. in pigs in slaughterhouses of Rio Grande do Sul, Brazil. Pesq Veter Brasil. 2004; 24: 80-84.

Brasil. Instruções para elaboração e implantação dos sistemas PPHO e APPCC nos estabelecimentos habilitados à exportação de carnes. Circular $\mathrm{N}^{\circ}$ 369/2003/DCI/DIPOA. 2003a.

Brasil. Métodos Analíticos Oficiais para Análises Microbiológicas para Controle de Produtos de Origem Animal e Água. Instrução Normativa $n^{\circ}$ 62, de 26 de agosto de 2003 - MAPA. 2003b.

Brasil. Ministério da Agricultura, Pecuária e Abastecimento - MAPA. Ofício Circular $\mathrm{n}^{\circ} 02$ Micro/CGAL/2010, de 26/04/2010 - Métodos Alternativos Aprovados - MAPA, Brasil. Instruções de uso das placas para contagem de aeróbios Petrifilm - 3M Método validado AOAC n ${ }^{\circ} 990.12$. 2010.

Dal Pissol A, Brustolin JC, Oliveira D, Valduga E, Toniazzo G, Cansian RL. The effect of water pressure and chlorine concentration on microbiological characteristics of spray washing broiler carcasses. Poultry Sci J. 2013. (in press).

Ercoline D, Russo F, Torrieri E, Masi P, Villani F. Changes in spoil a generated microbiota of beef during refrigerated storage under different packing conditions. Appl Environm Microbiol. 2006; 72: 4663-4671.

Gill CO, Dussault FHRA, Houde A, Jones T, Rheault $\mathrm{N}$, Rosales A, et al. Evaluation of the hygienic performances of the process for cleaning, dressing and cooling pig carcasses at eight packing plants. Inter J Food Microbiol. 2000; 58: 65-72. 
Gill CO. Effects on the microbiological condition of product of decontaminating treatments routinely applied to carcasses at beef packing plants. J Food Protect. 2009; 72: 1790-1801.

Haalan PD. Experimental design in biotechnology. New York: CRC Press. 1989.

Jung S, Ghoul M, Lamballerie-Anton M. Influence of high pressure on the color and microbial quality of beef meat, LWT - Food Sci Tech. 2003; 36: 625-631.

Lopes M, Galhardo JA, Oliveira JT, Tamanini R, Sanches SF, Muller EE. Pesquisa de Salmonella spp. e micro-organismos indicadores em carcaças de frango e água de tanques de pré-resfriamento em abatedouro de aves. Semina: Ciênc Agr. 2007; 28: 465-476.

Mcevoy JM, Doherty AM, Finnerty M, Sheridan JJ, Mcguire L, Blair IS, et al. The relationship between hide cleanliness and bacterial numbers on beef carcasses at a commercial abattoir. Lett Appl Microb. 2000; 30: 390-395.

Pearce RA, Bolton DJ, Sheridan JJ, Mcdowell DA, Blair IS, Harrington D. Studies to determine the critical control point in pork slaughter hazard analysis and critical control point systems. Int J Food Microbiol. 2004; 90: 331-339.

Pipek P, Houska M, Hoke K, Jelenicková J, Kyhos K, Sikulová M. Decontamination of pork carcasses by steam and lactic acid. J Food Engineer. 2006; 74: 224-231.
Regulation (EC) No 853/2004 of the European Parliament and of the Council of 29 April 2004, Official Journal of the European Union. 2004.

Smulders FJM, Wellm G, Hiesberger J, Bauer A, Paulsen P. The potential of the combined application of hot water sprays and steam condensation at subatmospheric pressure for decontaminating inoculated pig skin and muscle surfaces. Food Control. 2012; 24: 154-159.

Spescha C, Stephan R, Zweifel C. Microbiological contamination of pig carcasses at different stages of slaughter in two European Union-approved abattoirs. J Food Protect. 2006; 69: 2568-2575.

Tornadijo ME, Garca MC, Fresno JM, Carballo J. Study of Enterobacteriaceae during the manufacture and ripening of San Simon cheese. Food Microbiol. 2001; 18: 499-509.

Van Netten P, Mossel DAA, Huis in't Veld JHJ. Microbial changes on freshly slaughtered pork carcasses due to "hot" lactic acid decontamination. $J$ Food Saf. 1997; 17: 89-111. 